\title{
Toxicological effects of ciprofloxacin and chlorhexidine on growth and chlorophyll a synthesis of freshwater cyanobacteria
}

\author{
Fernanda Cristina Rezende Azevedo ${ }^{1 *}$, Izabela Cristina Dias Vaz', \\ Francisco Antônio Rodrigues Barbosa ${ }^{2}$, Sérgia Maria Starling Magalhães ${ }^{\circledR 1}$
}

\begin{abstract}
${ }^{1}$ College of Pharmacy, Federal University of Minas Gerais, Belo Horizonte, MG, Brasil, ${ }^{2}$ Institute of Biological Sciences, Federal University of Minas Gerais, Belo Horizonte, MG, Brasil
\end{abstract}

\begin{abstract}
Cyanobacteria are phytoplanktonic microorganisms that are susceptible to the deleterious effects of pharmaceutical residues in the aquatic environment, which poses a challenge to the environment exposed to diverse pharmaceutical products and their potential effects. The objective of this study was to evaluate the effects of the antibiotic substances ciprofloxacin and chlorhexidine in pharmaceutical preparations on the growth and production of chlorophyll of two cyanobacterial strains, Microcystis aeruginosa and Microcystis panniformis, isolated from a lake in a Brazilian environmental protection area. The $\mathrm{EC}_{50}$ and $\mathrm{EC}_{10}$ of chlorhexidine for $M$. aeruginosa were $206.4 \mu \mathrm{g} / \mathrm{L}$ and $108.5 \mu \mathrm{g} / \mathrm{L}$, respectively, and for $M$. panniformis were $171.4 \mu \mathrm{g} / \mathrm{L}$ and $116.6 \mu \mathrm{g} / \mathrm{L}$, respectively. The $\mathrm{EC}_{50}$ and $\mathrm{EC}_{10}$ of ciprofloxacin for $M$. aeruginosa were $17.24 \mu \mathrm{g} / \mathrm{L}$ and $3.21 \mu \mathrm{g} / \mathrm{L}$, respectively, and for $M$. panniformis were $13.56 \mu \mathrm{g} / \mathrm{L}$ and 1.50 $\mu \mathrm{g} / \mathrm{L}$, respectively. The toxicity of the antibiotic ciprofloxacin (drug) and chlorhexidine (standard solution) to the Microcystis species was demonstrated, and these species were both very sensitive to ciprofloxacin. Our results suggest that the strains of $M$. aeruginosa and $M$. panniformis may be affected by exposure to residues of ciprofloxacin $(>1.5 \mu \mathrm{g} / \mathrm{L})$, which may represent a risk to the survival of aquatic species.
\end{abstract}

Keywords: Ecotoxicological test. Antibiotics. Antiseptic. Contaminants of emerging interest. Growth inhibition.

\section{INTRODUCTION}

Recent decades have been marked by the intensification of pharmaceutical production and the introduction of new drugs (Kummerer, 2010; Baran et al., 2011). This has led directly to the release of a large amount of pharmaceutical residues and their metabolites into the environment (Le-Minh et al., 2010; Kummerer, 2010). Studies in different locations have shown the presence of these residues in water bodies (Watkinson et al., 2009), in hospital effluents (Segura et al., 2009; Vasconcelos et al., 2009; Rodrigues-Silva et al., 2014), in treatment waste water and sewage plants (Hirsch et al., 1999; Stumpf et al., 1999; Homem, Santos, 2011; Dorival-García et al., 2013; Zhang, 2014) and even in treated effluents (Östman et al., 2017) and drinking water (Yiruhan et al., 2010), demonstrating that conventional treatment processes are not fully effective in the removal of these residues.

\footnotetext{
*Correspondence: F. C. R. Azevedo. Faculdade de Farmácia, Universidade Federal de Minas Gerais, UFMG. Av. Presidente Antônio Carlos, 6627, Pampulha, Belo Horizonte/MG. E-mail: fernandauitfarma@yahoo.com.br
}

Drug residues from the use of pharmaceuticals by the community, from the disposal of unused products, and from industrial and hospital effluents reach aquatic environments in their free forms or as metabolites and may affect the survival of aquatic species (Fatta-Kassinos, Meric, Nikolaou, 2011). Among pharmaceuticals, antimicrobials have been of interest due to their effects on the biota of impacted environments since there is no selectivity for the antimicrobial effect, and these drugs can act on aquatic microorganisms in the same way as they act on human pathogens (Kummerer, 2009; Kummerer, 2010; Wang, Chu, 2016).

Cyanobacteria, a group of unicellular, photosynthetic, and cosmopolitan microorganisms, are among the aquatic organisms that are potentially exposed to antimicrobial actions. Cyanobacteria are found in lakes, rivers, oceans, rocks, and soils; the aquatic environment is one of the most important habitats for these species (Paerl, Paul, 2012; Catherine et al., 2013). Because they are primary producers, toxic effects on cyanobacteria can be observed at other trophic levels (Kummerer, 2009; Grinten et al., 2010). 
The potential effects of antimicrobial residues on cyanobacteria stem from the morphological and biochemical similarity of these organisms to other bacteria, especially gram-negative bacteria; thus, there is a risk that antimicrobials may interfere with the equilibrium of the aquatic ecosystem (Kummerer, 2009; Grinten et al., 2010; Fatta-Kassinos, Meric, Nicolaou, 2011). Resistance to antimicrobials can vary profoundly between cyanobacterial species and even between strains of the same species, which may compromise the equilibrium of aquatic communities (Lin et al., 2011). The constitutive or acquired resistance of these organisms is also of concern due to the possibility of exchange of resistance genes between other bacteria and cyanobacteria (Lin et al., 2011). It is important to highlight that cyanobacteria have the same components related to gene transmission as other bacteria, such as plasmids and transposable elements, that facilitate genetic exchange (Dias et al., 2015).

Among cyanobacteria, the genus Microcystis is considered to have the greatest dominance in the global environment (Soares et al., 2013), participating in the regulation of the balance of the aquatic ecosystem. However, some species of this genus may be potent toxin producers (Corbel, Mougin, Bouaicha, 2014). Toxic agents released into the aquatic environment can lead to cell lysis of toxigenic strains of Microcystis with the release of toxins and can cause serious sanitation problems (Fan et al., 2014).

Ciprofloxacin is one of the most commonly detected antibiotics in effluents in several parts of the world due to its stability in the aquatic environment and its intense hospital and community usage (Segura et al., 2009; Rodrigues-Silva et al., 2014). These characteristics led to ciprofloxacin being included in the list of the ten drugs with high priority in the water treatment cycle (Zhou, Jiang, 2015).

In a study in Brazil, Martins et al. (2008) analysed the presence of drugs in effluents from a university hospital and found ciprofloxacin concentrations of up to 155.0 $\mu \mathrm{g} / \mathrm{L}$. Ciprofloxacin concentrations have been reported in hospital effluents (Hartmann et al., 1998; Brown, 2004; Diwan, Lundborg, Tamhankar, 2013), as well as in aquatic environments in general (Kummerer, Henninger, 2003; Kummerer, 2009; Magdaleno et al., 2014; Östman et al., 2017) (Table I). Recently, Östman et al. (2017) detected residues of ciprofloxacin at all stages of sewage and wastewater treatment plants, including treated effluents (Table I).

Chlorhexidine is a substance with antimicrobial activity that has been used for more than 50 years, with multiple applications due to its excellent antiseptic and broad spectrum activities, as well as its low cost (Chantal et al., 2009; Das, Ghosh, Bhattacharjee, 2015). Chlorhexidine is probably the most widely used biocide in antiseptic products, in handwashing and in oral products as well as a disinfectant in hospitals and in veterinary uses such as skin cleaners, teat dips and antiseptics. Chlorhexidine is also used for cold sterilization of surgical instruments and for disinfecting equipment (Kahrs, 1995; McDonnell, Russell, 1999; Bottoni, Caroli, Caracciolol, 2010; Das, Ghosh, Bhattacharjee, 2015; Environment and Climate Change Canada, 2017). This drug acts non-specifically on the microflora of different environments, generally in

TABLE I - Detection of the antimicrobials ciprofloxacin and chlorhexidine in the aquatic environment

\begin{tabular}{|c|c|c|c|c|}
\hline Drug & Type of sample & Local Study & $\begin{array}{l}\text { Drug Concentration } \\
\text { detected }(\mu \mathrm{g} / \mathrm{L})\end{array}$ & Reference \\
\hline \multirow{4}{*}{ Ciprofloxacin } & $\begin{array}{c}\text { University hospital } \\
\text { wastewater }\end{array}$ & Switzerland & 3.0 to 87.0 & Hartmann et al., 1998 \\
\hline & Hospital wastewater & United States & 0.85 to 2.0 & Brown, 2004 \\
\hline & $\begin{array}{c}\text { University hospital } \\
\text { wastewater }\end{array}$ & Brazil & 19.0 to 155.0 & Martins et al., 2008 \\
\hline & Hospital wastewater & India & 3.07 & $\begin{array}{c}\text { Diwan, Lundborg, } \\
\text { Tamhankar, } 2013\end{array}$ \\
\hline
\end{tabular}


doses higher than antimicrobials of systemic use (Rizzotti, Rossi, Torriani, 2016).

According the Canadian document Draft Screening Assessment - Chlorhexidine and its Salts updated in 2017, chlorhexidine tends to persist in water, sediment and soil. Although chlorhexidine has a low potential to bioaccumulate in aquatic organisms, data from acute and chronic toxicity for chlorhexidine indicate that it has the potential to cause adverse effects on aquatic organisms at low concentrations.

Chlorhexidine has been detected in a medical waste water treatment plant (Matsushima, Sakurai, 1984) and in treated effluents (Östman et al., 2017). Magdaleno et al. (2014) predicted that chlorhexidine would reach a concentration of $382.0 \mu \mathrm{g} / \mathrm{L}$ in effluents from a hospital in the city of Buenos Aires, Argentina (Table I).

The extensive use of these two antimicrobial substances raises the need to assess their effects on aquatic species. It should be noted that in addition to the drug itself, drug formulations involve the use of excipients that seek to improve therapeutic properties, but they may also affect the toxicity of aquatic species (Silva et al., 2014), indicating the need for research on the toxic effects of pharmaceutical products.

Microcystis is the genus of cyanobacteria with the broadest distribution in Brazil (Bicudo, Menezes, 2006). Microcystis aeruginosa and Microcystis panniformis, species isolated from Rio Doce State Park in previous studies, are toxin producers. The effects of pollutants, particularly antibiotics, on toxigenic species are of concern due the risk of release of toxins in the water.

In this study, the effects of ciprofloxacin and chlorhexidine, as pharmaceutical products, on the growth and chlorophyll production of Microcystis aeruginosa and Microcystis panniformis isolated from Rio Doce State Park were evaluated.

\section{MATERIAL AND METHODS}

\section{Ciprofloxacin and chlorhexidine}

The drug used was a generic injectable ciprofloxacin $\left(0.2 \%\right.$ in $\left.\mathrm{H}_{2} \mathrm{O}\right)$, manufactured by the pharmaceutical company Isofarma Indústria Farmacêutica Ltda. Brazil, containing $\mathrm{NaCl}$, lactic acid, and hydrochloric acid $\left(\mathrm{Cl}^{-} 154 \mathrm{meq} / \mathrm{L}, \mathrm{Na}^{+} 154 \mathrm{meq} / \mathrm{L}\right)$. The standard solution of chlorhexidine digluconate $\left(20 \%\right.$ in $\left.\mathrm{H}_{2} \mathrm{O}\right)$ was obtained from Sigma-Aldrich - Germany. The nominal concentrations of the active pharmaceutical ingredients present in the products according to the manufacturer's information were used. The reagents, solvents, and chemicals used in this study were of analytical or chromatographic grade. All the solutions were prepared using Milli-Q water (Millipore ${ }^{\circledR}$, USA).

\section{Culture}

The cyanobacteria Microcystis aeruginosa and Microcystis panniformis were isolated from water samples collected in a lake located in Rio Doce State Park, Minas Gerais, Brazil. The species were maintained in culture in the cyanobacteria bank of the Laboratory of Limnology Ecotoxicology and Aquatic Ecology at the Biological Science Institute of the Federal University of Minas Gerais (LIMNEA-ICB-UFMG).

\section{Culture medium}

The medium used to culture $M$. aeruginosa and M. panniformis was ASM-1 (Gorham et al., 1964). The $\mathrm{pH}$ was adjusted to 7.0 with either $0.1 \mathrm{~mol} / \mathrm{LHCl}$ or $\mathrm{NaOH}$ solution.

\section{Cell counting}

The cells were counted in a Fuchs-Rosenthal counting chamber (New Optik $\left.{ }^{\circledR}\right)$ with trypan blue staining ( $1 \mathrm{~mL}$ of culture to $500 \mu \mathrm{L}$ trypan blue solution $2 \%$ ). After sedimentation of the cells (10 minutes), they were counted under an optical microscope (Olympus CBA). From the counts, growth curves were built.

\section{Optical Density (OD)}

After homogenization of the culture, $5 \mathrm{~mL}$ aliquots were removed and transferred into $10 \mathrm{~mm}$ cuvettes. The absorbance of the sample was determined at a wavelength of $700 \mathrm{~nm}$.

\section{Chlorophyll dosage}

After homogenization of the culture, vacuumfiltered $10 \mathrm{~mL}$ aliquots were removed. The membrane (Whatman GF/C $0.45 \mu \mathrm{m}$ ) was added to acetone $(5 \mathrm{~mL}$ ) as the extracting agent and macerated. The mixture was centrifuged for 20 minutes at $320.000 \mathrm{~g}$ (Sigma ${ }^{\circledR} 4 \mathrm{~K} 15$ ). The supernatant was transferred to a $10 \mathrm{~mm}$ quartz cuvette, and spectrophotometric readings were taken at four different wavelengths: $630 \mathrm{~nm}, 647 \mathrm{~nm}, 664 \mathrm{~nm}$ and $750 \mathrm{~nm}$. The chlorophyll a concentration was calculated using the Jeffrey and Humphrey method (Jeffrey, Humphrey, 1975) and is expressed in $\mathrm{mg} / \mathrm{L}$. 


\section{Growth inhibition tests}

Growth inhibition tests were performed following the OECD 201 Guidelines (2006), with some adaptations. Preliminary assays were conducted to establish the range of concentrations of ciprofloxacin and chlorhexidine separately to be used in the design of the experiments. A culture of cyanobacteria cells in the logarithmic phase of growth and containing approximately $10^{6} \mathrm{cell} / \mathrm{s} / \mathrm{mL}$ was inoculated in $250 \mathrm{~mL}$ erlenmeyer flasks containing $100 \mathrm{~mL}$ of ASM-1 medium. M. aeruginosa and M. panniformis were incubated, separately, at $25 \pm 2{ }^{\circ} \mathrm{C}$, under an irradiance of 98 mmoles. $\mathrm{m}^{-2} . \mathrm{s}^{1}$ and a 12 -hour photoperiod until a cellular density of $10^{6}$ cells $/ \mathrm{mL}$ was obtained. The cultures were distributed into erlenmeyer flasks in triplicate, with increasing concentrations of ciprofloxacin and chlorhexidine. Pre-cultured cyanobacteria, test solutions and controls were grown on a shaking table under the same conditions for 96 hours. Cell growth was measured daily by optical density (OD) measurement at $700 \mathrm{~nm}$ and chlorophyll dosage. All the experiments were carried out in triplicate.

\section{Determination of the $\mathrm{EC}_{50}$ and $\mathrm{EC}_{10}$ of chlorhexidine and ciprofloxacin for $M$. aeruginosa and M. panniformis}

For the growth inhibition tests on the cyanobacteria, the effective concentrations of drugs required for a $50 \%$ $\left(\mathrm{EC}_{50}\right)$ or $10 \%$ reduction in growth $\left(\mathrm{EC}_{10}\right)$ were calculated using a regression analysis of the relationship between the inhibition of growth rate $(r)$ and the concentration of the chlorhexidine or concentration of the ciprofloxacin on a natural logarithm (ln) scale. The inhibition growth rate coefficient $(r)$ for each culture (tests and controls) was calculated at 96 hours according to Equation 1:

$$
r=\ln \mathrm{X}_{1}-\ln \mathrm{X}_{0} / t_{1}-t_{0}
$$

where $\mathrm{X}_{0}$ and $\mathrm{X}_{1}$ are the number of cells (optical density) at 0 and 96 hours, respectively; $t_{0}$ denotes 0 days; $t_{1}$ denotes the fourth day; and $r$ is the average specific growth rate for the period $\left(\right.$ day $\left.^{-1}\right)(\mathrm{OECD}, 2006)$. A significant concentration was defined as a concentration exhibiting a statistically significant reduction in fecundity (at $p<0.05$, one way analysis of variance - ANOVA).

\section{RESULTS AND DISCUSSION}

To determine the sensitivity of the M. aeruginosa and M. panniformis species to ciprofloxacin and chlorhexidine, the concentration ranges of these substances were established from preliminary tests to construct the growth inhibition curve. The concentration ranges of ciprofloxacin used were $2.1 \mu \mathrm{g} / \mathrm{L}$ to $29.4 \mu \mathrm{g} / \mathrm{L}$ and from $1.6 \mu \mathrm{g} / \mathrm{L}$ to $39.0 \mu \mathrm{g} / \mathrm{L}$ for $M$. aeruginosa and $M$. panniformis, respectively. For chlorhexidine, the concentration range for inhibition of the growth of the species was considerably higher, from $111.37 \mu \mathrm{g} / \mathrm{L}$ to $235.8 \mu \mathrm{g} / \mathrm{L}$, and the same was used for both species.

Figure 1 shows the variations of the cell growth of the species exposed to the drugs for 96 hours.

For ciprofloxacin, a potent antimicrobial effect with irreversible growth inhibition at concentrations above $6.0 \mu \mathrm{g} / \mathrm{L}$ was observed after $48 \mathrm{~h}$ of exposure (Figures 1a and $1 \mathrm{c}$ ). The profile of the cyanobacterial growth inhibition curve of ciprofloxacin resembled that of Pasteurella multocida exposed to fluoroquinolones, as presented by Gehring and Riviere (2013), and those of several bacterial species reported by McKellar, Bruni and Jones (2004). This similarity was comparable to the similarity between the groups of bacteria and cyanobacteria.

It can be observed that the inhibitory effect of the growth of the species by ciprofloxacin was accentuated after $48 \mathrm{~h}$ of exposure. It is possible that this interval for the observation of effective inhibition of culture growth was due to the mechanism of action of ciprofloxacin. This antimicrobial acts intracellularly, inhibiting the enzyme DNA gyrase, making cell replication impossible; thus, the drug will have to penetrate the cell, meaning it takes time for it to reach the minimum inhibitory concentration for the effective inhibition of growth (Aldred, Kerns, Osheroff, 2014; Rodrigues-Silva et al., 2014).

At the highest tested concentrations of chlorhexidine $(197.0 \mu \mathrm{g} / \mathrm{L}$ and $236.0 \mu \mathrm{g} / \mathrm{L})$ (Figures $1 \mathrm{~b}$ and $1 \mathrm{~d}$ ), inhibition of cyanobacteria growth occurred in the first 48 hours, with a reduction of the initial cell population. From the third day on, the culture containing chlorhexidine resumed growth.

Chlorhexidine can act on a cell rapidly; depending on the concentration and the $\mathrm{pH}$, the maximum effect can occur within 20 seconds (McDonnell, Russell, 1999). After damage to the outer cell layers, the chlorhexidine molecules cross the cell membrane and attack the bacterial cytoplasm, followed by leakage of intracellular constituents. This mechanism of rapid action explains the early reduction of culture growth.

The recovery of the culture after the third day may have been due to cell adaptation mechanisms inherent to the species, or they may be acquired (McKella, Bruni, Jones, 2004). Another reason culture growth resumed might have been that all the drug had reacted or was 

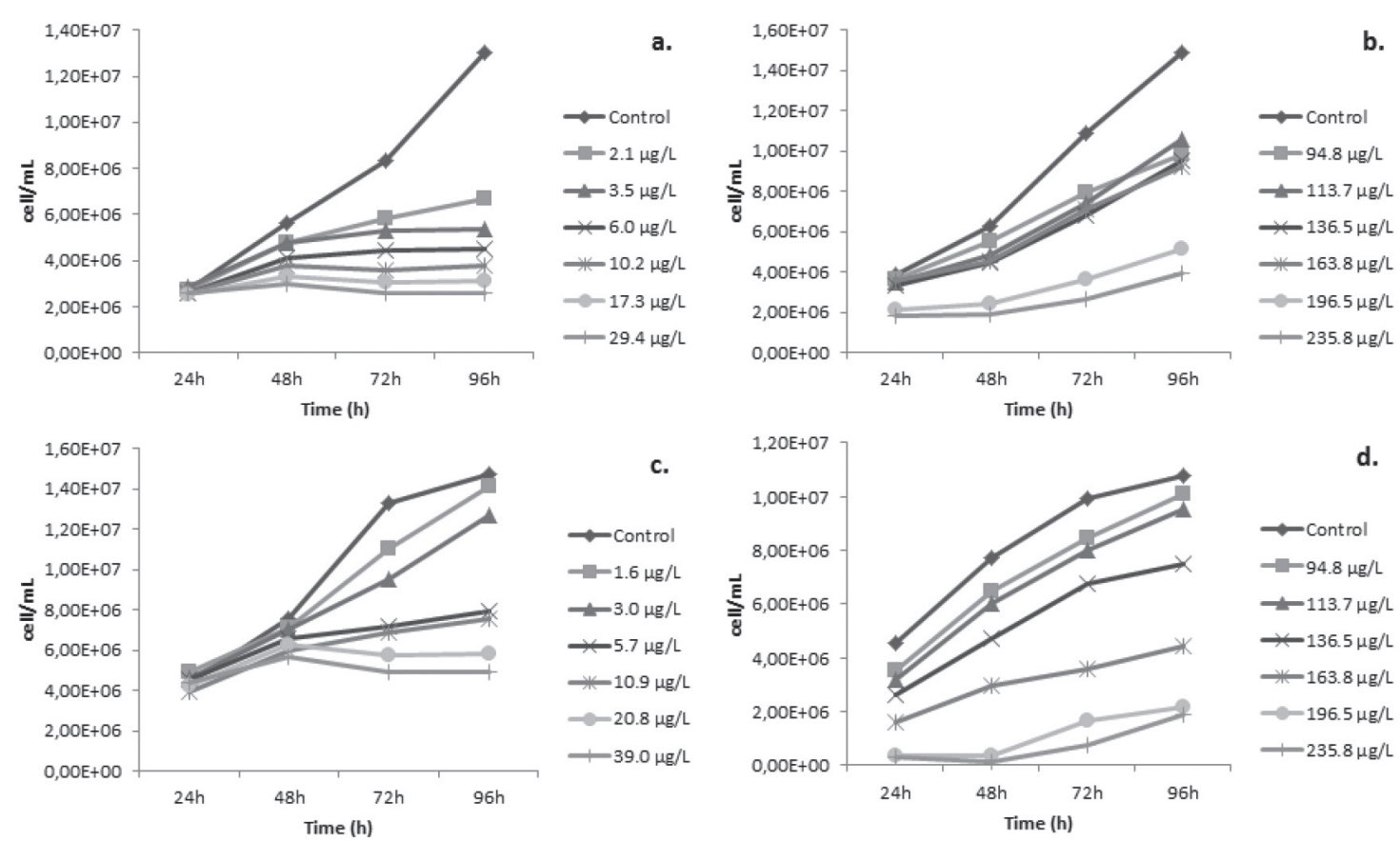

FIGURE 1 - Cellular density of M. aeruginosa exposed to (a) ciprofloxacin or (b) chlorhexidine. Cellular density of M. panniformis exposed to (c) ciprofloxacin or (d) chlorhexidine.

degraded. Chlorhexidine may undergo hydrolysis in alkaline solutions, yielding mainly p-chloroaniline (pCA) or reacting with different components of the medium (Mohammed, Abdel Aziz, 2017). pCA is the main product of its degradation pathway in alkaline conditions (Zong, Kirsch, 2012). According to Lin et al. (2015), light can also accelerate the by-product formation. pCA is very toxic if absorbed and may act as a human carcinogen (Mohammed, Abdel Aziz, 2017). According to Environment and Climate Change Canada (2017), chlorhexidine degradation in the natural environment is not significant, but in this study, the $\mathrm{pH}$, light, and composition of the culture medium may have accelerated the degradation process, leading to the formation of products such as para-chloroaniline. However, by-product formation was not investigated in this study. We considered that the toxicity was due to the total products - chlorhexidine and its by-products.

Growth inhibition curves as a function of concentration are shown in Figure 2. From the equations of the curves, the $\mathrm{EC}_{50}$ and $\mathrm{EC}_{10}$ were obtained for each species.

The growth inhibition curves as a function of ciprofloxacin concentration did not present a linear behaviour. According to Rodrigues-Silva et al. (2014), ciprofloxacin may show a bactericidal or bacteriostatic effect on microbial populations. According to Gehring and Riviere (2013), there is a complex relationship between the dose of an antimicrobial drug and its effect on microbial growth, which occurs by bacteriostatic or bactericidal actions, depending on the concentration. In these cases, the relationship between dose and growth-inhibitory effect may not be described by a linear relationship between these variables and may require more complex mathematical models to represent the dose-response curve (Czok, Keller, 2007).

Using the logarithm of the ratio of ciprofloxacin concentration to the growth-inhibitory effect (Figures 2a and $2 \mathrm{c}$ ), the concentrations that inhibited $50 \%$ of cell growth were calculated: $17.2 \mu \mathrm{g} / \mathrm{L}$ for M. aeruginosa and $13.5 \mu \mathrm{g} / \mathrm{L}$ for M. panniformis (Table I).

The $\mathrm{EC}_{10}$ of both antimicrobials was determined for the two species. The $\mathrm{EC}_{10}$ values of ciprofloxacin were 3.2 $\mu \mathrm{g} / \mathrm{L}$ and $1.5 \mu \mathrm{g} / \mathrm{L}$ for $M$. aeruginosa and M. panniformis, respectively (Table II). The $\mathrm{EC}_{10}$, according to the limitations of the biological test, might not differ significantly from the no-observed-effect concentration (NOEC) (FAO, WHO, 2008) and may indicate the concentration limit where the harmful effects to the organisms tested begin to be observed. However, in this study, the value of NOEC could not be estimated due to the set of concentrations used and the statistical limitations of the model. However, it is important to note that the calculated $\mathrm{EC}_{10}$ values were lower than the concentrations that have been detected in different environments (Hartmann et al., 1998; Kummerer, Henninger, 2003; Brown, 2004; Martins et al., 2008; Diwan, Lundborg, Tamhankar, 2013).

The $\mathrm{EC}_{50}$ values of chlorhexidine for M. aeruginosa and M. panniformis were $206.4 \mu \mathrm{g} / \mathrm{L}$ and $171.4 \mu \mathrm{g} / \mathrm{L}$, 

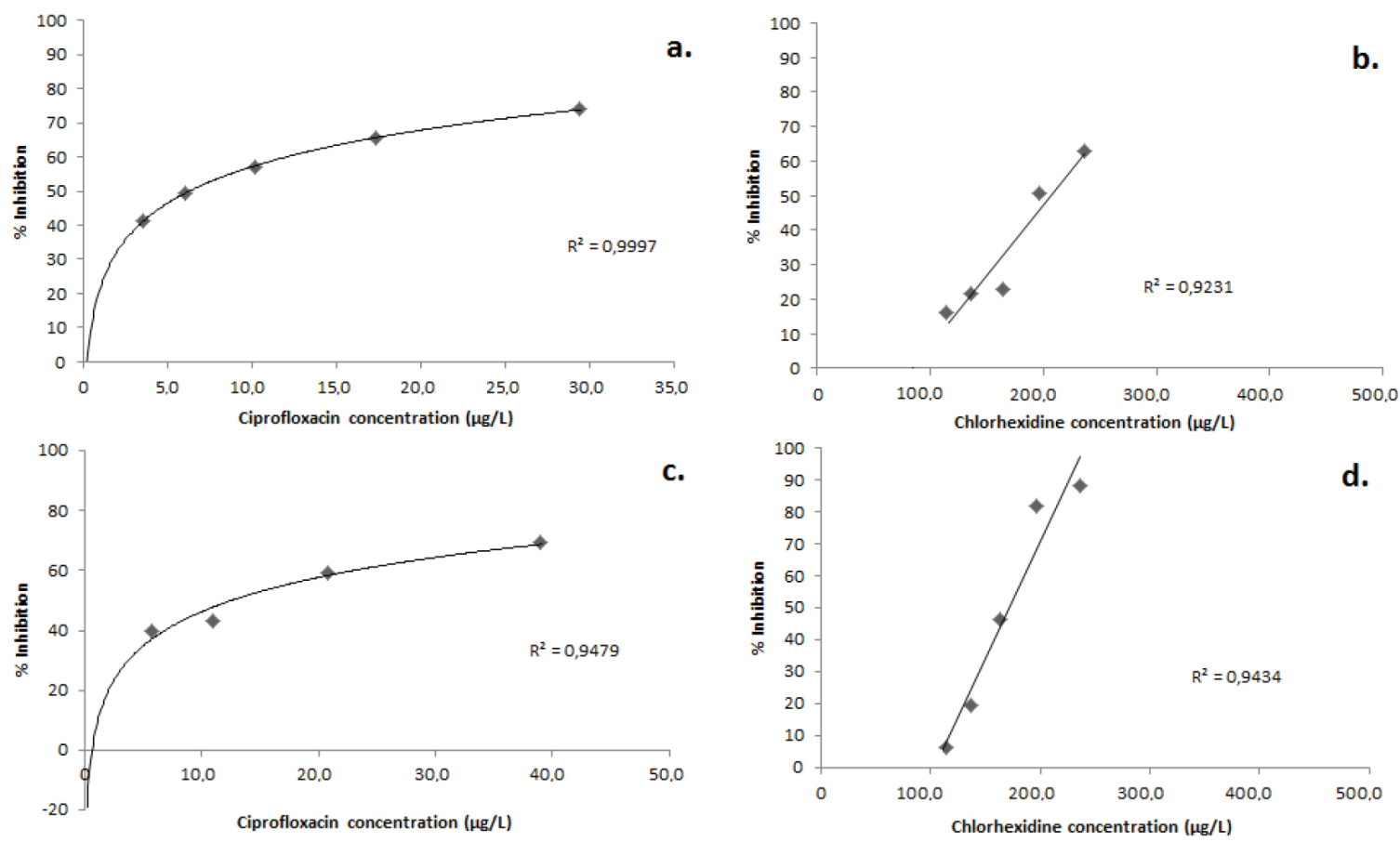

FIGURE 2 - Inhibition of growth of cultures of M. aeruginosa after 96 hours of exposure to ciprofloxacin (a) or chlorhexidine (b). Inhibition of growth of cultures of M. panniformis after 96 hours of exposure to ciprofloxacin (c) or chlorhexidine (d).

respectively. The $\mathrm{EC}_{10}$ values of chlorhexidine were calculated, following a linear model between the inhibition percentage and the concentration of the test substance since the curve had a linear correlation higher than 0.92 . Concentrations leading to $10 \%$ inhibition of the growth of the species were $108.5 \mu \mathrm{g} / \mathrm{L}$ and $116.6 \mu \mathrm{g} / \mathrm{L}$ for M. aeruginosa and M. panniformis, respectively (Table II).

Previous studies have reported the $\mathrm{EC}_{50}$ of pure ciprofloxacin on the cyanobacterium $M$. aeruginosa. Robinson, Belden and Lydy (2005) reported an $\mathrm{EC}_{50}$ of $17.0 \mu \mathrm{g} / \mathrm{L}$, and Halling-Sorensen et al. (2000) obtained an $\mathrm{EC}_{50}$ equal to $5.0 \mu \mathrm{g} / \mathrm{L}$. The inhibitory concentrations on $M$. aeruginosa found in our study are similar to those found by Robinson, Belden and Lydy (2005). The components of the injectable formulation other than ciprofloxacin apparently did add to the toxic effects evaluated in this study because the $\mathrm{EC}_{50}$ values were comparable to those reported in the literature for the nonformulated antimicrobial.

Comparing the results of the study by Robinson et al. (2005) with that of Halling-Sorensen et al. (2000) and our study, differences in sensitivity between strains of the same species are observed. Dias et al. (2015), studying the antibiotic susceptibility of nine isolates of Microcystis aeruginosa, reported that the strains might acquire antibiotic resistance due to environmentally selective pressure by previous antibiotic exposure or by the transference of antibiotic resistance genes from bacteria. Yang et al. (2013), in assays of repeated exposure to tetracycline of the freshwater cyanobacterium Microcystis aeruginosa, observed that the species acquired resistance to antibiotics after the first exposure.

TABLE II - Effective concentrations of ciprofloxacin and chlorhexidine $(\mu \mathrm{g} / \mathrm{L})$ leading to $10 \%\left(\mathrm{EC}_{10}\right)$ and $50 \%$ inhibition $\left(\mathrm{EC}_{50}\right)$ of Microcystis aeruginosa and Microcystis panniformis growth

\begin{tabular}{lccc}
\hline Antimicrobial Substances & Species & $\left.\mathbf{E C}_{\mathbf{1 0}} \boldsymbol{\mu g} / \mathbf{L} \mathbf{( 9 5 \%} \mathbf{C I}\right)$ & $\left.\mathbf{E C}_{\mathbf{5 0}} \boldsymbol{\mu g} / \mathbf{L} \mathbf{( 9 5 \%} \mathbf{~ C I}\right)$ \\
\hline \multirow{2}{*}{ Ciprofloxacin } & M. aeruginosa & $3.21[-0.66-7.09]$ & $17.24[1.76-32.72]$ \\
& M. panniformis & $1.50[0.16-2.83]$ & $13.56[6.92-20.21]$ \\
\hline \multirow{2}{*}{ Chlorhexidine } & M. aeruginosa & $108.47[105.45-111.50]$ & $206.38[200.01-212.63]$ \\
& M. panniformis & $116.62[112.79-120.45]$ & $171.42[169.34-173.49]$ \\
\hline
\end{tabular}

$\mathrm{EC}_{10}$ : effective concentration leading to $10 \%$ inhibition of species growth. $\mathrm{EC}_{50}$ : effective concentration leading to $50 \%$ inhibition of species growth. CI: confidence interval. 
It is possible that the origin of these species in different environments was related to their different levels of resistance to the same antimicrobial, depending on the mechanisms of acquired resistance, a widely demonstrated phenomenon in bacterial strains (Meagher et al., 2004; Aldred, Kerns, Osheroff, 2014).

Lawrence et al. (2008) observed the resistance of $M$. aeruginosa to chlorhexidine at concentrations of up to $100 \mu \mathrm{g} / \mathrm{L}$, without significant inhibitory effects, but the researchers did not report the $\mathrm{EC}_{50}$. In our study, the $\mathrm{EC}_{50}$ values of chlorhexidine for both species were also higher than $100 \mu \mathrm{g} / \mathrm{L}$. Jesus et al. (2013) described an $\mathrm{EC}_{50}$ of $62.2 \mu \mathrm{g} / \mathrm{L}$ for the algae Pseudokirchneriella subcapitata. This green algae, a common bioindicator, showed high susceptibility to chlorhexidine. The authors considered chlorhexidine very toxic to this species.

One of the most common mechanisms of phytoplankton toxicity is the inhibition of photosynthesis. Chlorophyll production by $M$. aeruginosa and M. panniformis was evaluated when exposed to chlorhexidine or ciprofloxacin at the same concentrations as in growth inhibition tests. The results are presented in Figure 3.

When estimating the production of chlorophyll per cell, it was observed that ciprofloxacin promoted a statistically significant inhibitory effect in both species compared to their respective controls (Figure 3a and $3 \mathrm{c})$, confirming the results observed by other researchers for different species of cyanobacteria exposed to various antimicrobials (Richards et al., 2004; Pan et al., 2009; Aristilde, Melis, Sposito, 2010; Liu et al., 2012; Qian et al., 2012). According to Aristilde, Melis, and Sposito (2010), molecular structures of antimicrobials of the fluoroquinolone class, containing a quinolone ring and a secondary amino group, may inhibit the key enzymes in electron transport in photosystem II. Ciprofloxacin, specifically, interferes with the transfer of energy from the excitation of the molecules at that PS-II reaction centre (Deng, Pan, Zhang, 2015).

When exposed to chlorhexidine, M. aeruginosa showed no significant differences in the production of chlorophyll a per cell (Figure 3.b). For M. panniformis, production was inhibited only at concentrations above $164.0 \mu \mathrm{g} / \mathrm{L}$ (Figure 3.d). These results indicate that chlorophyll biosynthesis appears to be one of the toxicity mechanisms of ciprofloxacin towards the Microcystis species evaluated and can be used for the calculation of $\mathrm{EC}_{50}$, as provided by the OECD protocol, but apparently is not suitable for the calculation for the inhibitory concentration of chlorhexidine.

There are some studies about growth inhibition of algae and cyanobacteria by antimicrobial agents, but it is not simple to compare them due different conditions of the tests and sources of the species. Yang et al. (2008) described the growth inhibition of the freshwater green alga Pseudokirchneriella subcapitata (Korschikov)

a.
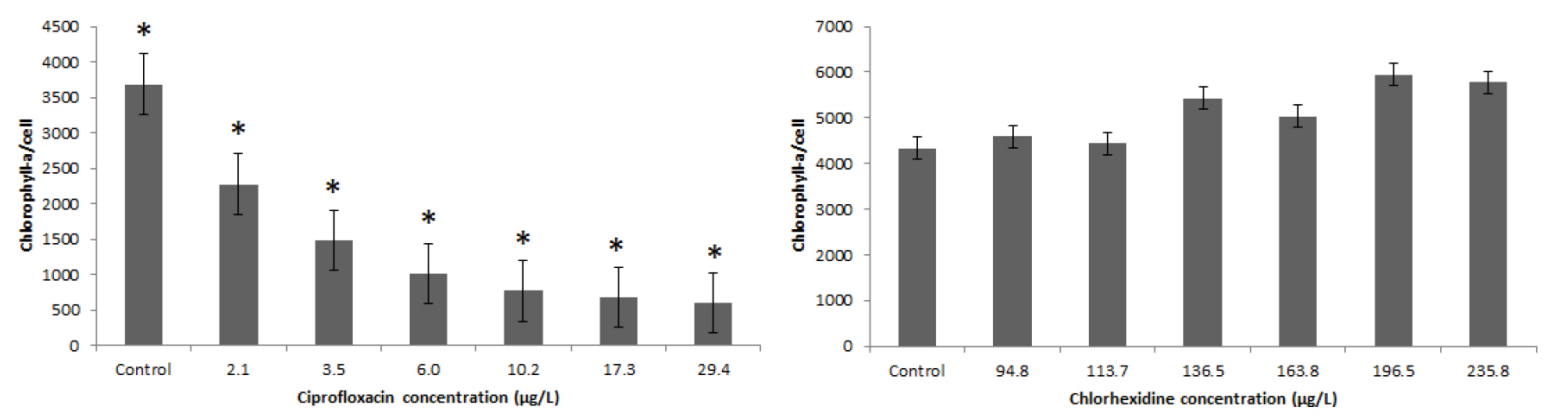

c.

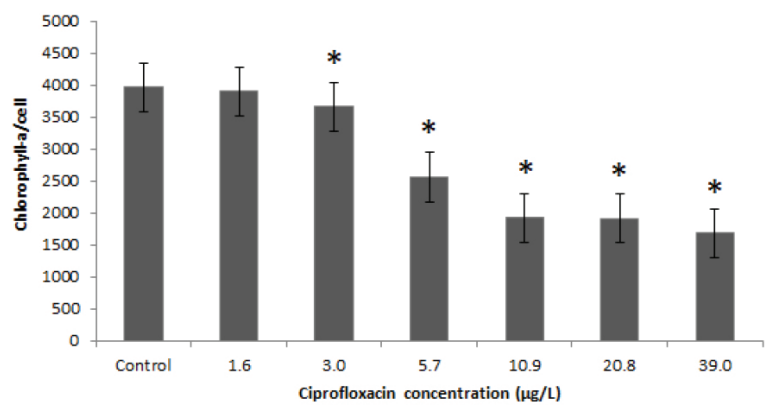

b.

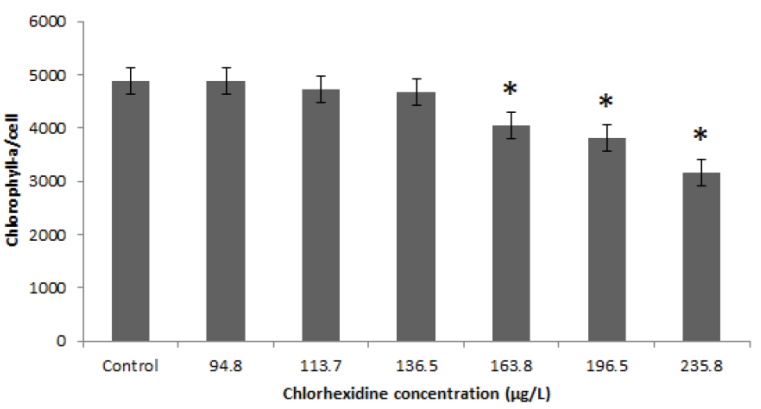

FIGURE 3 - Chlorophyll a/cell after 96 hours of exposure of M. aeruginosa to ciprofloxacin (a) or chlorhexidine (b); and of M. panniformis to ciprofloxacin $(\mathrm{c})$ or chlorhexidine $(\mathrm{d}) .(*)$ indicates a significant difference between the control and the tests $(\mathrm{P}<0.05)$. 
Hindák by 12 antibacterial agents, including ciprofloxacin, whose $\mathrm{IC}_{50}$ was $6,700 \mu \mathrm{g} / \mathrm{L}$. Hagenbuch and Pinckney (2012) evaluated the toxicity of ciprofloxacin towards two marine diatoms, Cylindrotheca closterium and Navicula ramosissima. The authors reported an $\mathrm{EC}_{50}$ equal to $55,430 \mu \mathrm{g} / \mathrm{L}$ for $C$. closterium and $72,120 \mu \mathrm{g} / \mathrm{L}$ for $N$. ramosissima. These values were generally higher than the $\mathrm{EC}_{50}$ for freshwater species.

The growth and chlorophyll a production of Microcystis flos-aquae exposed to fluoroquinolone levofloxacin were investigated by Wan, Guo and Zhang (2014). The results indicated that when the levofloxacin concentration exceeded $10.0 \mu \mathrm{g} / \mathrm{L}$, the growth of M. flos-aquae was significantly inhibited. Lützhoft, Halling-Sorensen and Jorgensen (1999) determined the $\mathrm{EC}_{50}$ values of several antimicrobials for M. aeruginosa, obtaining inhibitory concentrations ranging from $15.0 \mu \mathrm{g} / \mathrm{L}$ for sarafloxacin hydrochloride, a fluoroquinolone, to $112.0 \mu \mathrm{g} / \mathrm{L}$ for trimethoprim. Other antimicrobials evaluated in the same study included flumequine $\left(\mathrm{EC}_{50}=159.0 \mu \mathrm{g} / \mathrm{L}\right)$, oxolinic acid $\left(\mathrm{EC}_{50}=180.0 \mu \mathrm{g} / \mathrm{L}\right)$, oxytetracycline hydrochloride $\left(\mathrm{EC}_{50}=207.0 \mu \mathrm{g} / \mathrm{L}\right)$, and sulfadiazine $\left(\mathrm{EC}_{50}=135.0 \mu \mathrm{g} / \mathrm{L}\right)$.

Cyanobacteria are prokaryotes with a cell wall and a similar structure to gram-negative bacteria. Cyanobacteria share many metabolic processes with other bacteria and can possess a similar sensitivity to antibiotics. In this study, the species $M$. aeruginosa and $M$. panniformis were very sensitive to ciprofloxacin, and the $\mathrm{EC}_{50}$ of this drug was lower in some cases than the minimum inhibitory concentrations (MICs) for pathogenic species such as Haemophilus spp. (MIC 2,000 to 6,000 $\mu \mathrm{g} / \mathrm{L}$ ) (Andrews, 2001) and Salmonella typhimurium (MIC $25.0 \mu \mathrm{g} / \mathrm{L}$ ) (Diwan, Lundborg, Tamhankar, 2013).

In Brazil, ciprofloxacin has been detected in hospital effluent at a concentration of up to $155.0 \mu \mathrm{g} / \mathrm{L}$ (Martins et al., 2008), and in other countries it has been detected in surface waters at concentrations ranging from $0.005 \mu \mathrm{g} / \mathrm{L}$ to $0.74 \mu \mathrm{g} / \mathrm{L}$ (Rodrigues-Silva et al., 2014). Despite the dilution of the effluent in the natural aquatic environment, ciprofloxacin is a recalcitrant and poorly water-soluble contaminant that can be deposited in sediments (Frade et al., 2014). Furthermore, according to Lützhoft, Halling-Sorensen and Jorgensen (1999), the inhibitory concentrations of antimicrobials to certain aquatic species in laboratory settings may be underestimated for monoprotic and polyprotic compounds, such as ciprofloxacin, due to partitioning in the case of ionizable drugs. All of these aspects raise concerns about the environmental effects of antimicrobials
Chlorhexidine is also a persistent substance that can adsorb onto sediments. Although it presented a higher $\mathrm{EC}_{50}$ for the studied species of Microcystis, its wide use and the dearth of studies on its concentration in the environment generate concern about its environmental impact.

Our results suggest that $M$. aeruginosa and $M$. panniformis, common cyanobacteria in our environment, may be affected by exposure to ciprofloxacin, which may represent a risk to aquatic biodiversity.

\section{CONCLUSION}

The $\mathrm{EC}_{10}$ and $\mathrm{EC}_{50}$ of ciprofloxacin (pharmaceutical product) and chlorhexidine (standard solution) were determined for M. aeruginosa and M. panniformis. These species were very sensitive to ciprofloxacin, in terms of the $\mathrm{EC}_{50}$, compared to the inhibitory concentrations of other antimicrobials for cyanobacteria. Both species showed greater resistance to chlorhexidine. No data on chlorhexidine or ciprofloxacin concentrations are available in surface waters in Brazil. However, the presence of ciprofloxacin in hospital effluent has been reported, indicating its possible entry into the recipient water bodies. The $\mathrm{EC}_{10}$ of the test substances for the species evaluated, especially that of ciprofloxacin, are very low and alarming for environmental concerns. These results point to the need for studies to detect the presence of some drugs, including ciprofloxacin, in surface waters in Brazil, especially in water bodies that receive domestic or hospital effluent without adequate treatment.

\section{REFERENCES}

Aldred KJ, Kerns RJ, Osheroff N. Mechanism of quinolone action and resistance. Biochemistry. 2014;53(10):1565-1574.

Andrews JM. Determination of minimum inhibitory concentrations. J Antimicrob Chemoth. 2001;48(Supl 1):5-16.

Aristilde L, Melis A, Sposito G. Inhibition of photosynthesis by a fluoroquinolone antibiotic. Environ Sci Technol. 2010;44(4):1444-1450.

Baran AW, Adamek E, Ziemianska J, Sobczak A. Effects of the presence of sulfonamides in the environment and their influence on human health. J Hazard Mater. 2011;196:1-15.

Bicudo CEM, Menezes M. Gêneros de algas de águas continentais do Brasil: chave para identificação e descrições. 2 ed, São Carlos: Rima; 2006. 
Bottoni P, Caroli S, Caracciolo BA. Pharmaceuticals as priority water contaminants. Toxicol Environ Chem. 2010;92(3):549565.

Brown KD. Pharmaceutically Active Compounds in Residential and Hospital Effluent, Municipal Wastewater, and the Rio Grande in Albuquerque, New Mexico; 2004.

Catherine Q, Susanna W, Isidora ES, Mark H, Aurélie V, JeanFrançois H. A review of current knowledge on toxic benthic freshwater cyanobacteria e ecology, toxin production and risk management. Water Res. 2013;47(15):5464-5479.

Chantal W, Jang Hj, Toghrol F, Bentley We. Global transcriptomic response of Pseudomonas aeruginosa to chlorhexidine diacetate. Environ Sci Technol. 2009;43(21):8406-15.

Corbel S, Mougin C, Bouaicha N. Cyanobacterial toxins: Modes of actions, fate in aquatic and soil ecosystems, phytotoxicity and bioaccumulation in agricultural crops. Chemosphere. 2014;96:1-15.

Czok D, Keller F. Mechanism-based pharmacokineticpharmacodynamic modeling of antimicrobial drug effects. J Pharmacokinet Pharmacodyn. 2007;34(6):727-751.

Das R, Ghosh S, Bhattacharjee C. A green practice for pharmaceutical drug chlorhexidine digluconate treatment and ecotoxicity assessment. J Water Proc Eng. 2015;7:266-272.

Deng C, Pan X, Zhang D. Influence of ofloxacin on photosystems I and II activities of Microcystis aeruginosa and the potential role of cyclic electron flow. J Biosci Bioeng, 2015;119(2):159164.

Dias E, Oliveira M, Jones-Dias D, Vasconcelos V, Ferreira E, Manageiro V, et al. Assessing the antibiotic susceptibility of freshwater Cyanobacteria spp. Front Microbiol. 2015;6:799.

Diwan V, Lundborg Cs, Tamhankar AJ. Seasonal and temporal variation in release of antibiotics in hospital wastewater: estimation using continuous and grab sampling. PLoS One. 2013;8(7).e68715.

Dorival-García N, Zafra-Gómez A, Cantarero S, Navalón A, Vílchez Jl. Simultaneous determination of 13 quinolone antibiotic derivatives in wastewater samples using solid-phase extraction and ultra-performance liquid chromatographytandem mass spectrometry. Microchem J. 2013;106:323-333.
Enviroment and Climate Change Canada - ECCC. Updated Draft screening assessment: chlorhexidine and its salts. Aug. 2017. 52 p. Available in: <http://www.ec.gc.ca/ese-ees/59BDF713391A-4F47-8FB3-E3E4651C943A/Chlorhexidine\%20Moiety_ En.pdf>. Accessed on: may 012018.

Fan J, Hobson P, Ho L, Daly R, Brookes J. The effects of various control and water treatment processes on the membrane integrity and toxin fate of cyanobacteria. J Hazard Mater. 2014;264:313322 .

Fatta-Kassinos D, Meric S, Nikolaou A. Pharmaceutical residues in environmental waters and wastewater: current state of knowledge and future research. Anal Bioanal Chem. 2011;399(1):251-275.

Frade V, Dias M, Teixeira A, Palma M. Environmental contamination by fluoroquinolones. Braz J Pharm Sci. 2014;50(1):41-54.

Food and Agriculture Organization. FAO. World Health Organization. WHO. Dose-response assessment. Principles and methods for the risk assessment of chemicals in food. Switzerland: WHO Press; 2008. p. 1-55.

Gehring R, Riviere JE. Limitations of MIC as the sole criterion in antimicrobial drug dosage regimen design: The need for full characterization of antimicrobial pharmacodynamic profile especially for drug-resistant organisms. Vet J. 2013;198(1):1518.

Gorham PR, Mclachlan J, Hammer UT, Kim WK. Isolation and culture of toxic strains of Anabaena flos-aquae (Lyngb.) de Bréb. Verh Internat Verein Limnol. 1964;15(2):796-804.

Grinten E, Pikkemaat Mg, Van Den Brandhof Ej, Stroomberg $\mathrm{Gj}$, Kraak Mh. Comparing the sensitivity of algal, cyanobacterial and bacterial bioassays to different groups of antibiotics. Chemosphere. 2010;80(1):1-6.

Hagenbuch IM, Pinckney JL. Toxic effect of the combined antibiotics ciprofloxacin, lincomycin, and tylosin on two species of marine diatoms. Water Res. 2012;46(16):5028-5036.

Halling-Sorensen B, Lützhoft Hc, Andersen Hr, Ingerslev F. Environmental risk assessment of antibiotics: comparison of mecillinam, trimethoprim and ciprofloxacin. J Antimicrob Chemoth. 2000;46(1):53-58. 
Hartmann A, Alder AC, Koller T, Widmer RM. Identification of fluoroquinolone antibiotics as the main source of $u m u C$ genotoxicity in native hospital wastewater. Environ Toxicol Chem. 1998;17(3):377-382.

Hirsch R, Ternesa T, Haberera K, Kratzb KL. Occurrence of antibiotics in the aquatic environment. Sci Total Environ. 1999;225(1-2):109-118.

Homem V, Santos L. Degradation and removal methods of antibiotics from aqueous matrices - A review. J Environ Manage. 2011;92(10):2304-2347.

Jeffrey SW, Humphrey GF. New espectrofotometric equations for determining chlorophylls a,b, c and c2 in higher plants, algal and natural phytoplankton. Biochem Physiol Planzen. 1975;167(2):191-194.

Jesus FT, Oliveira R, Silva A, Catarino AL, Soares AM, Nogueira AJ, Domingues I. Lethal and sub lethal effects of the biocide chlorhexidine on aquatic organisms. Ecotoxicology. 2013;22(9):1348-1358.

Kahrs RF. General disinfection guidelines. Rev Sci Tech. 1995;14(1):105-122.

Kummerer K, Henninger A. Promoting resistance by the emission of antibiotics from hospitals and households into effluent. Clin Microbiol Infect. 2003;9(12):1203-1214.

Kummerer K. Antibiotics in the aquatic environment - A review - Part I. Chemosphere. 2009;75(4):417-434.

Kummerer K. Pharmaceuticals in the environment. Annu Rev Environ Resour. 2010;35:57-75.

Lawrence J, Zhu B, Swerhone Gd, Topp E, Roy J, Wassenaar $\mathrm{Li}$, et al. Community-level assessment of the effects of the broad-spectrum antimicrobial chlorhexidine on the outcome of river microbial biofilm development. Appl Environ Microbiol. 2008;74(11):3541-3550.

Le-Minh N, Khan SJ, Drewes JE, Stuetz RM. Fate of antibiotics during municipal water recycling treatment processes. W Res. 2010;44(15):4295-4323.

Lin S, Haas S, Zemojtel T, Xiao P, Vingron M, Li R. Genomewide comparison of cyanobacterial transposable elements, potential genetic diversity indicators. Gene. 2011;473(2):139149.
Lin SC, Huang CF, Shen LJ, Wang HJ, Lin CY, Lin Wu FL. Formulation and stability of an extemporaneous $0.02 \%$ chlorhexidine digluconate ophthalmic solution. J Formos Med Assoc. 2015;114(12):1162-1169.

Liu Y, Guan Y, Gao B, Yue Q. Antioxidant responses and degradation of two antibiotic contaminants in Microcystis aeruginosa. Ecotoxicol Environ Saf. 2012;86:23-30.

Lützhoft HC, Halling-Sorensen B, Jorgensen SE. Algal toxicity of antibacterial agents applied in danish fish farming. Arch Environ Contam Toxicol. 1999;36(1):1-6.

Magdaleno A, Juárez AB, Dragani V, Saenz ME, Paz M, Moretton J. Ecotoxicological and genotoxic evaluation of Buenos Aires city (Argentina) Hospital Wastewater. J Toxicol. 2014;2014:248461.

Martins AF, Vasconcelos T, Henriques D, Frank C, König A, Kümmerer K. Concentration of ciprofloxacin in Brazilian Hospital effluent and preliminary risk assessment: a case study. Clean. 2008;36(3):264-269.

Matsushima H, Sakurai N. A selected ion monitoring assay for chlorhexidine in medical waste water. Biomed Mass Spectrom. 1984;11(5):203-206.

McDonnell G, Russell AD. Antiseptics and disinfectants: activity, action, and resistance. Clin Microbiol Rev. 1999;12(1):147-179.

McKellar QA, Bruni S, Jones DG. Pharmacokinetic/ pharmacodynamic relationships of antimicrobial drugs used in veterinary medicine. J Vet Pharmacol Ther. 2004;27(6):503-14.

Meagher AK, Forrest A, Dalhoff A, Stass H, Schentag JJ. Novel pharmacokinetic-pharmacodynamic model for prediction of outcomes with an extended-release formulation of ciprofloxacin. Antimicrob Agents Chemother. 2004;48(6):2061-2068.

Mohammed TG, Aziz AMEM. Development and validation of a simple, fast, isocratic stability indicating RP-HPLC-UV method for the determination of chlorhexidine and its impurity para-chloroaniline in bulk and finished product. IOSR J Pharm. 2017;7(6):1-8.

OECD GUIDELINE 201. Freshwater alga and cyanobacteria, growth inhibition test. Organization for Economic Co-operation and Development, Paris. 2006. 
Östman M, Lindberg RH, Fick J, Björn E, Tysklind M. Screening of biocides, metals and antibiotics in Swedish sewage sludge and wastewater. Water Res. 2017;115:318-328.

Paerl HW, Paul VJ. Climate change: Links to global expansion of harmful Cyanobacteria. Water Res. 2012;46(5):1349-1363.

Pan X, Zhang D, Chen X, Mu G, Li L, Bao A. Effects of levofloxacin hydrochlordie on photosystem II activity and heterogeneity of Synechocystis sp. Chemosphere. 2009;77(3):413-418.

Qian H, Li J, Pan X, Sun Z, Ye C, Jin G, et al. Effects of Streptomycin on Growth of Algae Chlorella vulgaris and Microcystis aeruginosa. Environ Toxicol. 2012;27(4):229-237.

Richards SM, Wilson CJ, Johnson DJ, Castle DM, Lam M, Mabury SA, et al. Effects of pharmaceutical mixtures in aquatic microcosms. Environ Toxicol Chem. 2004;23(4):1035-1042.

Rizzotti L, Rossi F, Torriani S. Biocide and antibiotic resistance of Enterococcus faecalis and Enterococcus faecium isolated from the swine meat chain. Food Microbiol. 2016;60:160-164.

Robinson AA, Belden JB, Lydy MJ. Toxicity of fluoroquinolone antibiotics to aquatic organisms. Environ Toxicol Chem. 2005;24(2):423-430.

Rodrigues-Silva C, Maniero M, Peres M, Guimarães JR. Ocorrência e degradação de quinolonas por processos oxidativos avançados. Quim Nova. 2014;37(5):868-885.

Segura PA, François M, Gagnon C, Sauvé S. Review of the occurrence of anti-infectives in contaminated wastewaters and natural and drinking waters. Environ Health Persp. 2009;117(5):675-84.

Silva A, Santos LH, Delerue-Matos C, Figueiredo SA. Impact of excipients in the chronic toxicity of fluoxetine on the alga Chlorella vulgaris. Environ Technol. 2014;35(21-24):3124-29.

Soares MCS, Huszar V, Miranda M, Mello M, Roland F, Lürling M. Cyanobacterial dominance in Brazil: distribution and environmental preferences. Hydrobiologia. 2013;717(1):1-12.

Stumpf M, Ternes TA, Wilken RD, Rodrigues SV, Baumann W. Polar drug residues in sewage and natural waters in the state of Rio de Janeiro, Brazil. Sci Total Environ. 1999;225(1-2):135141.
Vasconcelos T, Kümmerer K, Henriques DM, Martins AF. Ciprofloxacin in hospital effluent: degradation by ozone and photoprocesses. J Hazard Mat. 2009;169(1-3):1154-1158.

Wan J, Guo P, Zhang S. Response of the cyanobacterium Microcystis flos-aquae to levofloxacin. Environ Sci Pollut Res Int. 2014;21(5):3858-3865.

Wang J, Chu L. Irradiation treatment of pharmaceutical and personal care products (PPCPs) in water and wastewater: An overview. Radiat Phys Chem. 2016;125:56-64.

Watkinson AJ, Murby EJ, Kolpin DW, Costanzo SD. The occurrence of antibiotics in an urban watershed: From wastewater to drinking water. Sci Total Environ. 2009;407(8):2711-2723.

Yang LH, Ying GG, Su HC, Stauber JL, Adams MS, Binet MT. Growth-inhibiting effects of 12 antibacterial agents and their mixtures on the freshwater microalga Pseudokirchneriella subcapitata. Environ Toxicol Chem. 2008;27(5):1201-1208.

Yang W, Tang Z, Zhou F, Zhang W, Song L. Toxicity studies of tetracycline on Microcystis aeruginosa and Selenastrum capricornutum. Environ Toxicol Pharmacol. 2013;35(2):320324.

Yiruhan, Wang QJ, Mo CH, Li YW, Gao P, Tai YP, et al. Determination of four fluoroquinolone antibiotics in tap water in Guangzhou and Macao. Environ Pollut. 2010;158(7):23502358.

Zhang Q, Jia A, Wan Y, Liu H, Wang K, Peng H, et al. Occurrences of three classes of antibiotics in a natural river basin: association with antibiotic-resistant Escherichia coli. Environ Sci Technol. 2014;48(24):14317-14325.

Zhou Z, Jiang JQ. Reaction kinetics and oxidation products formation in the degradation of ciprofloxacin and ibuprofen by ferrate (VI). Chemosphere. 2015;119(Suppl):95-100.

Zong Z, Kirsch LE. Studies on the instability of chlorhexidine, part I: kinetics and mechanisms. J Pharm Sci. 2012;101(7):241727.

Received for publication on $17^{\text {th }}$ October 2017 Accepted for publication on $03^{\text {th }}$ August 2018 